\title{
Excessive Nitrogen Fertilizer Application Causes Rapid Degradation of Greenhouse Soil in China
}

\author{
Xiaobing Wang1,2*, Xiaoli Wang ${ }^{1}$, Haijun Sheng, ${ }^{1,2}$, Xiaozhi Wang ${ }^{1,2}$, \\ Haitao Zhao ${ }^{1,2}$, Ke Feng ${ }^{1,2}$ \\ ${ }^{1}$ College of Environmental Science and Engineering, Yangzhou University, Yangzhou 225127, China \\ ${ }^{2}$ Jiangsu Collaborative Innovation Center for Solid Organic Waste Resource Utilization, Nanjing, 210095, China
}

Received: 16 September 2021

Accepted: 23 October 2021

\begin{abstract}
Greenhouse cultivation has expanded for years to provide vegetables for a growing population in China. It's reported that total area of greenhouse soil has reached 4.708 million hectares in 2019. To maintain good productivity, a large quantity of fertilizers was continuously applied to the soil. Due to low nitrogen $(\mathrm{N})$ use efficiency, excessive nutrients are accumulated in soil profile. As a result, greenhouse soil is often compromised by the secondary soil salinization. This paper summarized the typical characteristics of secondary salinization of greenhouse soil such as nitrate accumulation and soil acidification as a result of excessive $\mathrm{N}$ application. The adverse impacts of soil salinization were also reviewed on major physical, chemical and biological properties of soil. It can be found that many physiological diseases due to nutrient disorder and soil borne diseases because of changes in soil microflora, are associated with higher salt concentration in soil and the lower soil $\mathrm{pH}$. To reclaim the degraded soil with high nitrate concentration, an economical and environmentally friendly approach by incorporation of appropriate amount of plant materials with high $\mathrm{C} / \mathrm{N}$ ratio into the soil was discussed. It was demonstrated that biomass addition could promote humification of nitrate with the help of microorganisms.
\end{abstract}

Keywords: nitrogen fertilizer, China, greenhouse soil, degradation, secondary salinization

\section{Introduction}

With increasing demand for vegetables and horticultural products, the greenhouse cultivation area is expanding at an unimaginable rate. According to Ministry of Agriculture and Rural Affairs, PRC, the total area of planting facilities, mainly plastic greenhouses, solar greenhouses and terraces, will be

e-mail: xbwang@yzu.edu.cn stabilized at more than 2 million hectares by 2025 , which was just 20 thousand hectares in 1980 .

However, under such special conditions as higher temperature, humidity, evaporation, planting intensity, multiple cropping index, and large amounts of fertilizer application, lack of rainwater leaching and so on, greenhouse soils are susceptible to degradation characterized by deteriorated physical properties, secondary salinization and acidification [1], imbalance of soil nutrients and microbial flora, increased crop diseases and insect pests, etc $[2,3]$. 
Despite the lack of nationwide statistics on the area and extent of deteriorated greenhouse soil, the severity of greenhouse soil degradation has been well documented in some recent work. For example, Tang reported that $78.26 \%$ of 30 greenhouse planting sites located in Shanghai of China have suffered from secondary soil salinization [4]. Qu analyzed soil samples from 170 greenhouses Lishui City of Zhejiang Province in Southeast China and found that 93.8\% of them had become saline soil [5]. Li et al. found the occurrence of secondary salinization exceeded $40 \%$ in $6.50 \times 10^{5}$ ha greenhouse soil in Shandong province of Eastern China [6].

However, to date, there is no comprehensive reviews concerning the occurrence, characterization, outcome and reclamation of the secondary salinization of greenhouse soil. The purposes of this review were to summarize the dominant properties of saline soil as a result of excessive $\mathrm{N}$ fertilizer application, the associated mechanisms of this phenomenon and major reactions in soil, the effects of secondary salinity on soil physicochemical properties and microorganisms, and common practices to remediate the degraded soil.

\section{Characteristics of Secondary Salinization of Greenhouse Soil in Salt Composition and Its Distribution in Soil Profile}

For open land cultivation, the dissolved ions in soil come mainly from fertilization and groundwater irrigation, in addition to native soil ions. Under greenhouse conditions, however, the amount of chemical fertilizer input is mostly 4.1 times, as much as that applied in open-air field, in order to achieve higher economic benefits [7]. According to a survey in Shandong province by Shi et al., fertilizer application rate was over $2554.5 \mathrm{~kg} \mathrm{ha}^{-1}$ and $3234.0 \mathrm{~kg} \mathrm{ha}^{-1}$ in cucumber and tomato producing areas [8]. In Shaanxi province, the inputs of $\mathrm{N}, \mathrm{P}$ and $\mathrm{K}$ were 829,554 and $619 \mathrm{~kg} \cdot \mathrm{hm}^{-2}$, respectively [9]. Obviously, fertilizer usage is far more than the actual nutrient demand by plants. Based on the analysis of 79 experimental data from 57 sources related to plant tomato fertilization in
China, the average utilization rate of nitrogen was less than $10 \%$ under traditional nitrogen management [10]. Thus, some reseachers suggested that excessive application of chemical fertilizer, especially $\mathrm{N}$ fertilizer, was the direct cause of salt accumulation in greenhouse soil [11].

The degraded greenhouse soil is predominantly characterized by high salt concentrations in soil profile. The ions that result in secondary soil salinization mainly comprise four anions $\left(\mathrm{HCO}_{3}^{-}, \mathrm{Cl}^{-}, \mathrm{SO}_{4}^{2-}, \mathrm{NO}_{3}\right)$ and four cations $\left(\mathrm{Ca}^{2+}, \mathrm{K}^{+}, \mathrm{Mg}^{2+}, \mathrm{Na}^{+}\right)[12,13]$. However, there are no consensus as to the ions that play leading roles in the secondary salinization process. The disagreement may be due to differences in soil types, fertilizer species and dosages, irrigation water quality and irrigation method, or planting systems. For example, inland calcareous soils and alkaline soils contain higher concentrations of $\mathrm{HCO}_{3}^{-}$originating from weathering of carbonate minerals. Chloride ion in topsoil was mainly introduced by $\mathrm{Cl}^{-}$rich irrigation water and $\mathrm{Cl}^{-}$-containing fertilizers such as $\mathrm{KCl}$ and $\mathrm{NH}_{4} \mathrm{Cl}$; besides, $\mathrm{Cl}^{-}$can move upwards to surface soil due to capillary forces in coastal regions with high water tables [14]. Sulfate ion in most soils comes mainly from sulphur-containing fertilizers such as $\left(\mathrm{NH}_{4}\right)_{2} \mathrm{SO}_{4}$ and $\mathrm{K}_{2} \mathrm{SO}_{4}$, and the organic fertilizers with Sulphur [14]. Nitrate in soil mainly derives from nitrate-N fertilizers and nitrification of ammonium $\mathrm{N}$. Regarding four major cations, they are incorporated into soil by fertilizer application and dissolution of soil minerals [15].

In the greenhouse environment, the accumulation of salt in surface soil is much higher than that in open soil in a short time. $\mathrm{Xu}$ reported that 20 years after converting open-air planting to greenhouse planting, the nitrate concentrations in $0-20 \mathrm{~cm}$ soil layer had been increased by 4 times [16]. Some researchers have found that electrical conductivity (EC) of some greenhouse soils could be 10 times higher than that of open-field soils [17]. After secondary salinization, hardpan could be formed in topsoil, and some abnormal phenomena such as "white frost" and "reddening" could be observed on soil surfaces (Fig. 1). In soils with "white frost", 2-4\% salt content could be observed, whereas "reddening" surfaces occurred with salt content of

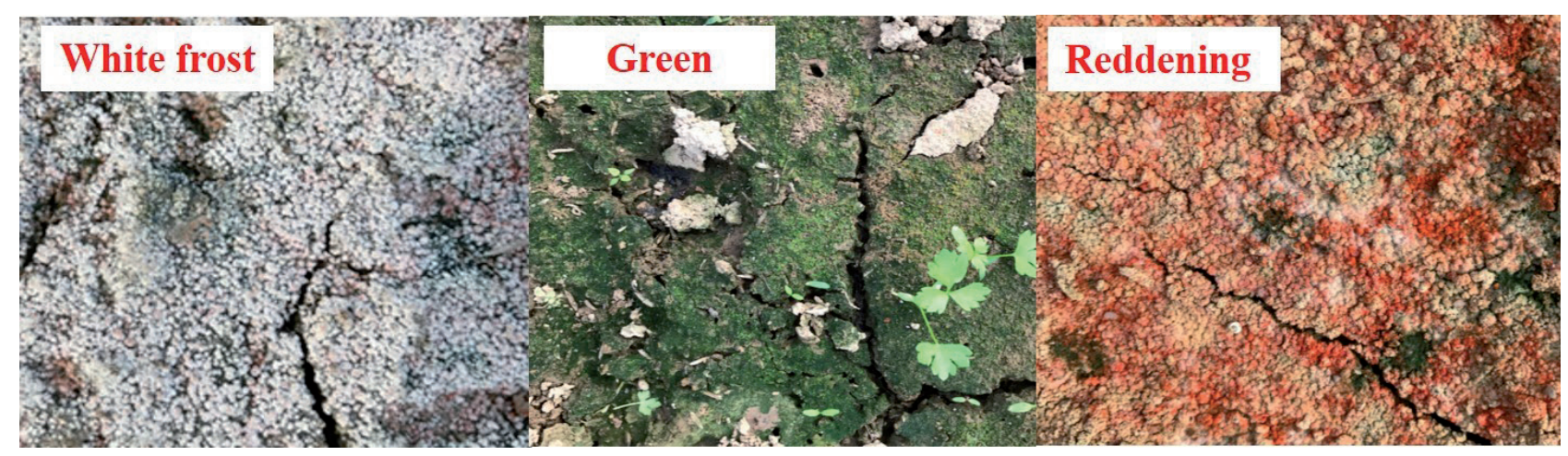

Fig.1. Surface characteristics of secondary salinized soil with different salt contents (Photos taken by Haijun Shen, 2018). 
6-10\% or above when purple-looking Porphyridium spp. could be colonized [18].

The salt distribution mainly depends on the direction of water movement in the soil profiles. In the greenhouse management practices, the frequent and small-scale irrigation could not flush salts out of soil profile. Under high temperatures and strong evaporation conditions, soil water then moved upward along soil profile with dissolved salts, which remain in the top $15 \mathrm{~cm}$ soil [19]. That is, greenhouse soil showed a different salt distribution pattern compared to natural soil layers.

\section{Nitrate Accumulation Caused by Excessive $\mathrm{N}$ Application has become the Main Cause of Secondary Salinization}

As $30-35^{\circ} \mathrm{C}$ is the optimum temperature for nitrification, the higher temperature in greenhouse facilities is therefore very conducive to the conversion of $\mathrm{NH}_{4}^{+}$to $\mathrm{NO}_{3}^{-}$. Thus, the excessive use of $\mathrm{N}$ fertilizers directly results in the accumulation of $\mathrm{NO}_{3}^{-}$in soil [20]. Yang et al. found that $\mathrm{NO}_{3}^{-}$had accounted for $65.95 \%$ of total anions in some greenhouse soils with relatively long period of cultivation [21]. Besides, the release of protons during nitrification could enhance dissolution of $\mathrm{Ca}^{2+}$ and $\mathrm{Mg}^{2+}$ bearing soil minerals, which indirectly increases salt concentration in soil solution [22]. In recent years, it's commonly found that $\mathrm{NO}_{3}^{-}-\mathrm{N}$ concentration in surface soil of greenhouse is more than $1000 \mathrm{mg} \mathrm{kg}^{-1}$ [18], or even above $4000 \mathrm{mg} \mathrm{kg}^{-1}$ (unpublished data). Liu et al. analyzed $\mathrm{NO}_{3}{ }^{-}$and salt contents of 0-10, 10-20, 20-40, 40-60, 60-80 and 80-100 $\mathrm{cm}$ of greenhouse soils in Qinghai Province in Western China, which had been cultivated for 2, 5, 10, 15, 22 and 27 years, respectively [23]. The results showed that soil $\mathrm{NO}_{3}^{-}-\mathrm{N}$ content was significantly correlated with total salt content, but very low with total N, alkalihydrolyzed N, and almost not with organic matter content. Many other studies have confirmed that there was a significantly positive correlation between $\mathrm{NO}_{3}^{-}-\mathrm{N}$ content and total salt content in greenhouse soil [24]. These observations demonstrated that excessive use of $\mathrm{N}$ fertilizer has become the main factor leading to the sudden increase of soil salinity in greenhouse.

Electrical conductivity (EC) of soil extracts are often used to indicate the degree of soil salinization [25]. However, the contribution of each ions to $\mathrm{EC}$ varies in different soils, which depends mainly on the parent materials, fertilizer types and application rates, ion composition of irrigation water and irrigation methods in different regions. Yuan et al. reported that in offshore areas with high $\mathrm{Cl}^{-}$concentration in groundwater, EC showed greater correlation with $\mathrm{Cl}^{-}$[26], and the results of Yang et al. [17], however, showed that there were statistically significant relationships between $\mathrm{NO}_{3}^{-}$contents and soil EC in the surface soils of greenhouse in the middle and lower reaches of the Yangtze River.

\section{Rapid Acidification of Greenhouse Soil Caused} by Excessive Use of N Fertilizers

Besides salinization, the rapid acidification is another characteristic of secondary salinization in greenhouse soil. Under natural conditions soil acidification is a slow process which is attributed to unbalanced generation and consumption of $\mathrm{H}^{+}$ion due to combined actions of many factors [27]. In greenhouse production system, however, this process has been rapidly accelerated by anthropogenic activities [28, 29]. Researches have showed that the application of large amounts of $\mathrm{N}$-containing fertilizers increased the accumulation of nitrate in surface soil layer, which is accompanied by the rapid decrease of soil $\mathrm{pH}$ [30]. The significantly negative correlation between soil $\mathrm{EC}$ and $\mathrm{pH}$ was also confirmed in serval previous work [31]. This feature is considered to be a most characteristic feature of deteriorated greenhouse soils, since the co-occurrence of salinization and soil acidification is seldomly found in open-land field soils [29].

Several processes could result in acidification of greenhouse soil. First, residual acidic ions such as $\mathrm{NO}_{3}^{-}, \mathrm{SO}_{4}^{2-}, \mathrm{Cl}^{-}$can remain in soil solution due to selective absorption of cations in acidifying fertilizers by plants [32]. Second, the generation of carbonic acid is more favored because of greater availability of $\mathrm{CO}_{2}$ in greenhouse, which can be derived from root respiration and other anthropogenic activities [33]. Third, large amounts of organic acids, which are secreted by plant roots or generated by decomposition of organic fertilizers, could complex with weaklybonded cations and thus enhance the downward movement of these base cations [34]. Fourth, under high salt conditions, $\mathrm{H}^{+}$on soil colloids could be exchanged by cations and then enters into soil solution [35]. Recent studies have found that high concentrations of $\mathrm{NO}_{3}^{-}$ could combine with $\mathrm{Ca}^{2+}$ and promote $\mathrm{Ca}^{2+}$ leaching, which could therefore increase $\mathrm{H}^{+}$saturation on soil colloids and enhance soil acidification [36]. The result of $\mathrm{Ma}$ et al. showed that $\mathrm{NO}_{3}^{-}$concentration was positively correlated with soil EC, but negatively correlated with soil $\mathrm{pH}$ [37]. Many other works have confirmed that nitrification has become the main acidification process in greenhouse soils, with longer cultivation times and continuous input of large amount of $\mathrm{N}$ fertilizer [38].

Relative to acid deposition and other acid generation processes, nitrification of $\mathrm{N}$-containing fertilizer is recognized as the main factor leading to greenhouse soil acidification [32]. The extent of soil acidification as a result of $\mathrm{N}$ fertilizer application is very dependent on types of $\mathrm{N}$ fertilizers [32], for example, $\left(\mathrm{NH}_{4}\right)_{2} \mathrm{SO}_{4}$ was 3.0 times of $\mathrm{NH}_{4} \mathrm{NO}_{3}$ or $\mathrm{CO}\left(\mathrm{NH}_{2}\right)_{2}$ with respect to their ability to acidify soils [39]. This is ascribed to different transformation reactions for various $\mathrm{N}$ fertilizers in soil. For example, $\mathrm{NH}_{3}$ is generated by ammonization of $\mathrm{N}$-containing organic fertilizers, but $\mathrm{NH}_{4}^{+}$is preferably formed for chemical fertilizers, 


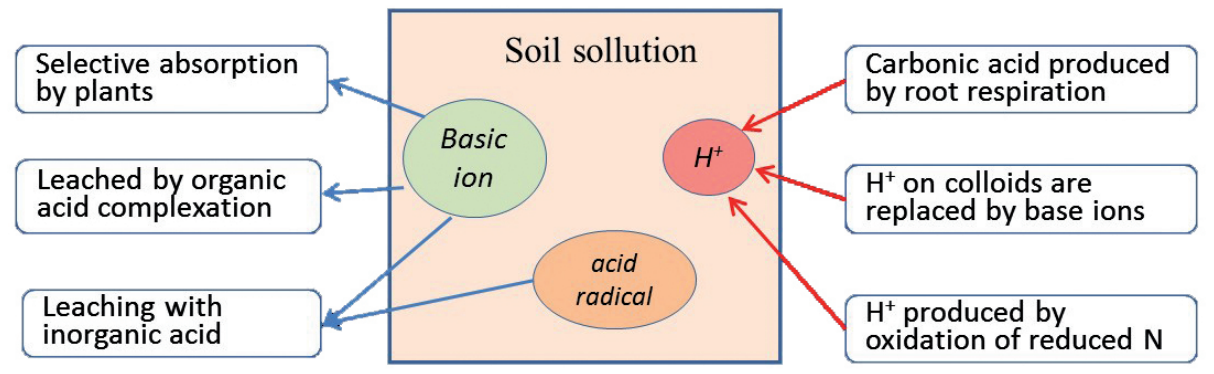

Fig. 2. Factors causing $\mathrm{pH}$ decline of greenhouse soil.

whereas urea can eventually be converted to $\mathrm{NO}_{3}{ }^{-}$under aerobic conditions.

$$
\begin{gathered}
\mathrm{NH}_{3}+2 \mathrm{O}_{2} \rightarrow \mathrm{H}^{+}+\mathrm{NO}_{3}^{-}+\mathrm{H}_{2} \mathrm{O} \\
2 \mathrm{NH}_{4}^{+}+4 \mathrm{O}_{2} \rightarrow 4 \mathrm{H}^{+}+2 \mathrm{NO}_{3}^{-}+2 \mathrm{H}_{2} \mathrm{O} \\
\mathrm{CO}\left(\mathrm{NH}_{2}\right)_{2}+4 \mathrm{O}_{2} \rightarrow 2 \mathrm{H}^{+}+2 \mathrm{NO}_{3}^{-}+\mathrm{H}_{2} \mathrm{O}+\mathrm{CO}_{2}
\end{gathered}
$$

The conversion to $\mathrm{NO}_{3}{ }^{-}$generates different amounts of $\mathrm{H}^{+}$in the process of transformation (Eqs (1)-(3)). Han quantified the $\mathrm{H}^{+}$production in relation to $\mathrm{N}$ conversion of urea in greenhouse soils of Shouguang Vegetable Base in Shandong Province, which showed about $0.92 \mathrm{~mol}$ of $\mathrm{H}^{+}$was released for generation of every 1 mol $\left(\mathrm{NO}_{2}^{-}+\mathrm{NO}_{3}^{-}\right)-\mathrm{N}$ in soil [29]. He reported that total $\mathrm{H}^{+}$was predicted as much as $14.3-27.3 \mathrm{kmol}$ $\mathrm{H}^{+}$ha ${ }^{-1}$ and $12.1-58.2 \mathrm{kmol} \mathrm{H}^{+}$ha ${ }^{-1}$, with $\mathrm{N}$ fertilizer input rates of $600 \mathrm{~kg}$ and $1,200 \mathrm{~kg} \mathrm{~N} \mathrm{ha}^{-1}$ respectively. Proton budgeting calculation demonstrated that the proton released from leafy vegetables (for example lettuce) due to excessive uptake of cations only accounted for $0.3-4.5 \%$ of that from nitrification, implying that nitrification is a major contributor for acidification of greenhouse soil.

\section{Soil Acidification and Nitrate Accumulation Lead to Deterioration of Soil Physical and Chemical Properties}

Acidification and nitrate accumulation can cause a series of changes in physical and chemical properties of greenhouse soils. One of the most obvious changes in physical properties concerns destroyed soil aggregates due to leaching of calcium ions, which makes soil more compacted, less aerated and water permeable. Because of not favorable soil properties, the salt in topsoil cannot be moved downward into deeper soil with irrigation water, which was aggravated by upward movement of salts due to capillary forces [40]. As a result, a hardsalinized layer, or hardpan, could be formed on the subsurface of the soil. With respect to soil chemical properties, soil acidification mainly affects the processes of redox, precipitation and dissolution, adsorption and desorption of ions in soil. Under acidic conditions, base cations adsorbed on soil colloids are more likely to be replaced by $\mathrm{H}^{+}$and $\mathrm{Al}^{3+}$ and further leached out of soil profile, leading to the decreased soil buffering capacity [36]. Moreover, the higher temperature in greenhouse is conductive to the mineral weathering and thus promotes release of base cations from minerals in the process of soil acidification, which further promotes secondary salinization [40].

\section{Nitrate Accumulation and Soil Acidification Cause the Changes of Soil Microbial Community and Increase of Soil-Borne Diseases}

The accumulation of nitrate and the decrease of soil $\mathrm{pH}$ may further affect the microbial community composition in soil [41, 42]. With the barcoded pyrosequencing method, Shen et al. found that the bacterial OTU phylotype richness and phylogenetic diversity were generally lower in soils with higher $\mathrm{N}$ fertilization rates in a greenhouse-based intensive vegetable agriculture system, in eastern China [43]. The results of Han et al. showed that short-term excessive fertilization increased soil nutrient contents and the diversity of nitrifying microbial communities, however, the abundance and diversity of nitrifying communities decreased greatly due to the increase of soil acidity and salinity after 14 years of high fertilization in a greenhouse [41]. The results of redundancy analysis (RDA) showed that the population structure of nitrifying

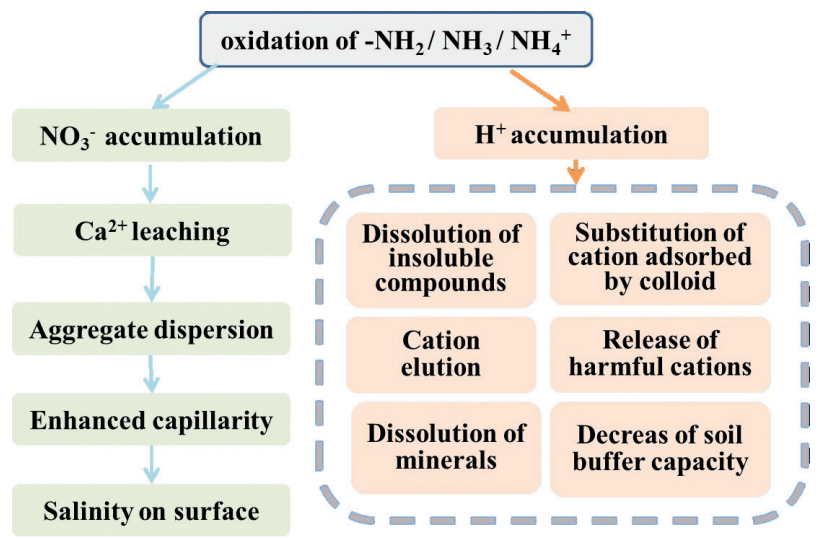

Fig. 3. Effects of nitrification on physical and chemical properties of soil. 
microorganisms in greenhouse soil was significantly correlated with soil Electrical Conductivity (EC) and $\mathrm{NO}_{3}{ }^{-}$content, and soil potential nitrification (PNA) and ammonia-oxidizing bacteria (ABO) were significantly affected by change of $\mathrm{pH}$ values, and more specifically, abundance and diversity of nitrifying microorganisms decreased significantly with the increase of soil acidity and salinity [29].

Some reports have confirmed that with the increase of continuous planting time, soil microorganisms present a transformation from "bacterial type" to "fungal type" [44, 45]. It should be noted that this trend is consistent with the decreasing trend of soil $\mathrm{pH}$ in greenhouse. Wang et al. (2018) reported that the number of soil bacteria was positively correlated with soil $\mathrm{pH}$ value and negatively with $\mathrm{NO}_{3}^{-}$[46], in contrast, the number of fungi was negatively correlated with soil $\mathrm{pH}$, but positively correlated with soil $\mathrm{NO}_{3}^{-}$. Ouyang et al. explained that as neutral and slightly alkaline soils are more conducive to the survival of bacteria and actinomycetes [47] and low $\mathrm{pH}$ is more beneficial to fungal growth [48]. Therefore, soil $\mathrm{pH}$ is considered to be the most important factor affecting the community structure of bacteria and fungi [49].

Soil acidification may also alter the diversity and dynamic balance of microbial flora, which is an important basis for inhibiting soil-borne diseases [1, 42]. As the dominant microbial communities was from bacteria to fungi, there are increase on density of nematodes and the soil-borne diseases but decrease on beneficial antagonistic bacteria such as growthpromoting bacteria, and the density of actinomycetes [36]. A study with greenhouse soils showed that in the initial stage of greenhouse cultivation, the dominant fungi in soil are saprophytic fungi, which are mainly responsible for decomposition of cellulose and lignin in soil. After several years of continuous planting, the transformation of dominant fungi into parasitic fungi occurred, and there was a large increase of pathogenic fungi such as Helminthosporium longum and Alternaria alternate [50]. Wang et al. found that in acidified soils, soil-borne diseases such as bacterial wilt, and fusarium wilt of fruit vegetables and leaf vegetables got aggravated with planting time [51]. It was reported that soil use patterns could affect community diversity of Bacillus spp. and Pseudomonas spp., which was correlated with the inhibition level of soil-borne diseases [52]. For example, the number of Fusarium oxysporum was negatively correlated with its capacity to control the cucumber fusarium wilt [53]. Bélec et al. and Rashid et al. also pointed out the acidification of greenhouse soil was an important factor inducing root swelling of cruciferous vegetables [54].

Besides, soil acidification and excessive nitrate have a strong effect on activity of important enzymes of microorganisms in soil. Dehydrogenase activity is an indicator of microbial redox system, which is usually used to estimate the oxidative capacity of soil microorganisms. Yin et al. confirmed that dehydrogenase activity was positively correlated with soil $\mathrm{pH}$ value $(\mathrm{r}=0.92 * *)$, and negatively with $\mathrm{NO}_{3}^{-}$ content in soil $\left(\mathrm{r}=-0.76^{* *}\right)$ [55]. Among soils with different utilization modes, the lowest dehydrogenase activity of microorganisms was found in greenhouse soil.

\section{Soil Acidification and Nitrate Accumulation Cause Plant Nutrition Disorder and Physiological Diseases}

It has been recognized that, in contrast to natural saline soils, secondary soil salinization is characterized by excessive accumulation of $\mathrm{NO}_{3}^{-}$with high proportion in anions, which is believed to be one of the leading factors causing physiological obstacles of greenhouse plants [56]. The decrease of soil $\mathrm{pH}$ and accumulation of nitrate can not only promote the dissolution of soil minerals and precipitates containing $\mathrm{P}, \mathrm{Fe}, \mathrm{Al}, \mathrm{Mn}, \mathrm{Cu}$, $\mathrm{Zn}, \mathrm{Ca}, \mathrm{Mg}$ and $\mathrm{Mo}$, but enhance desorption of ligands on solid phases [15]. This would inevitably increase ion concentrations in soil solution. This is likely ascribed to toxicity of high concentrations of dissolved Al and Mn to plants, and deficiency of some plant essential nutrients such as $\mathrm{P}, \mathrm{Ca}, \mathrm{Mg}, \mathrm{Mo}$ at lower pHs [57]. Wang et al. found that disease incidence and severity of blossom-end rot, top rot, malformed fruit, split stem, floal sterility in fruit vegetables were more pronounced in acidified greenhouse soils [51].

\section{Control Measures for Secondary Salinization}

In China, some strategies have been adopted to cope with the degradation of greenhouse soils. To improve soil physical properties, the effective practices include amending soils with soil conditioners such as biochar and minerals, replacing topsoil with foreign soils or overturning surface soil [58]. Besides, excessive salts in surface soil can be taken up by halophile plants or aquatic plants [59] or mitigated by proper water management practices including burying concealed tubes [60, 61], flood irrigation [62, 63], building a less-dense soil interlayer with straw to cut off upward capillary water movement [64]. These measures can slow down the degradation of greenhouse soil characterized by nitrate accumulation and acidification in the short term and inhibit soil-borne diseases or physiological diseases to a certain extent. However, these practices are proved not effective to reclaim the degraded soils in the long run, some of which could even cause additional environmental pollution. For intense, $\mathrm{NO}_{3}^{-}$leached out of soil profile by flood irrigation, accumulates in surface and groundwater with considerable concentrations [65].

The authors believe that transformation of nitrate to organic $\mathrm{N}$ may offer an ultimate solution to current problems associated with soil acidification. As is well accepted, $\mathrm{C} / \mathrm{N}$ ratio in soil should be maintained in a suitable range for the microorganisms to perform 
their functions. Thus, it is practical to adjust soil $\mathrm{C} / \mathrm{N}$ ratio by virtue of incorporation of extra $\mathrm{C}$ source to soil in an effort to promote $\mathrm{N}$ immobilization. To confirm our hypotheses, field experiments were performed by adding organic materials (straw, rice husk, sawdust, and other biomass) along with certain degrading bacteria to greenhouse soils with high nitrate concentration. The results demonstrated that $\mathrm{NO}_{3}^{-}$concentration was reduced to an appropriate concentration in a short time, and its adverse impact on plant growth has been greatly reduced [18]. In the process of transforming $\mathrm{NO}_{3}^{-}$into organic $\mathrm{N}, \mathrm{NO}_{3}{ }^{-}$was first reduced to $\mathrm{NH}_{3}$, a process that consumes $\mathrm{H}^{+}$:

$$
\mathrm{NO}_{3}^{-}+8 \mathrm{H}^{+}+8 \mathrm{e}^{-} \rightarrow \mathrm{NH}_{3}+2 \mathrm{H}_{2} \mathrm{O}+\mathrm{OH}^{-}
$$

Meanwhile, a large amount of $\mathrm{HCO}_{3}^{-}$was released during decomposition of carbon materials, which increases soil $\mathrm{pH}$. Our results clearly confirmed that application of organic materials could resolve the problems of soil acidity and salinity due to overuse of $\mathrm{N}$ fertilizers, and improve soil physicochemical properties for optimal plant growth. However, this technique may be challenged in practical application, and further researches should be done to understand decomposition rates and $\mathrm{C}$ release characteristics of different organic, and the optimal concentration of nitrate in soil for different plants.

\section{Conclusions}

In China, secondary salinization has become a common phenomenon of problematic greenhouse soils. One of the main reasons is that too much $\mathrm{N}$ fertilizer is applied, which is far beyond plant requirements. The excessive $\mathrm{N}$ is converted to nitrate that accounts for half or even more than two-thirds of all anions in greenhouse soils. The oxidation of reduced $\mathrm{N}$ is usually accompanied by the production of $\mathrm{H}^{+}$, which consequently leads to a decrease of soil $\mathrm{pH}$. The high nitrate content and acidification of soil can make plants more susceptible to physiological diseases such as nutrient disorder. Besides, this can disturb the diversity and balance of soil microflora, which is believed to depress beneficial microbes, promote shift from bacteria to fungus-dominated microbial communities, and therefore aggravate soil borne diseases. In this review, some common practices have been summarized to remediate the greenhouse soil with secondary salinization. A new concept was also proposed by incorporating plant biomass (straw, rice husk, sawdust, and other biomass) to soil in order to adjust the $\mathrm{C} / \mathrm{N}$ ratio of soil, which could greatly alleviate nitrate accumulation by promoting its transformation to organic $\mathrm{N}$, increasing soil organic matter, and effectively improve plant productivity.

\section{Acknowledgments}

This work was supported by the National Basic Research Program of China (No. 2013CB127404), the National Natural Science Foundation of China (No. 41471236), the Agricultural Science and Technology Innovation Fund of Jiangsu Province (CX(20)3082; CX(17)3043).

\section{Conflict of Interest}

The authors declare no conflict of interest.

\section{Reference}

1. LI J., XU Y., LIU H.G. Variations of soil quality from continuously planting greenhouses in North China. International Journal of Agricultural and Biological Engineering, 12 (1), 139, 2019.

2. KRISHI G., KENDRA V., GORAKHPUR U., PRADESH I., SINGH R. Important diseases of greenhouse crops and their integrated management: a review. Journal of Entomology and Zoology Studies, 8 (1), 962, 2020.

3. PASCUAL J., ROZAS M.M., ROJO M.A., ROS M. Soil fungicides to control soil-borne diseases of Mediterranean crops grown under greenhouse. Acta Horticulturae, 179, 2020.

4. TANG D., MAO L., ZHI Y.E., ZHANG J.Z., ZHOU P., CHAI X.T. Investigation and Canonical Correspondence Analysis of Salinity Contents in Secondary Salinization Greenhouse Soils in Shanghai Suburb. Environmental Science, 35 (12), 4705, 2014.

5. QU Y.M. Investigation on secondary salinization of vegetable soils in Liandu, Lishui. Journal of Zhejiang Agricultural Science, 58 (12), 2188, 2017. in Chinese with English abstract.

6. LI T., YU L., WU Y., WAN G.H., LI J.W. Secondary salinization of greenhouse vegetable soils and its affecting factors in Shandong Province, China. Acta Pedologica Sinica, 55 (1), 100, 2018 [In Chinese with English abstract].

7. HUANG S.W., TANG J.W., LI C.H., ZHANG H.Z., YUAN S. Reducing potential of chemical fertilizers and scientific fertilization countermeasure in vegetable production in China. Journal of Plant Nutrition and Fertilizer, 23 (6), 1480, 2017 [In Chinese with English abstract].

8. SHI N., LI Y., JING Y., BO L., ZHANG Y., SUN M., ZHONG Z. Effect of long-term fertilization on spatiotemporal changes and risk of nitrogen and phosphorus loss in intensive vegetable production system soil. Journal of Agro-Environment Science, 37 (11), 2434, 2018 [In Chinese with English abstract].

9. LI R., HU F., LI S.L., SHI L., WANG X.Y., TONG Y.A. Evaluation of fertilization status of facility vegetables in Shaanxi Province. Modern Agricultural Science and Technology, 16, 53, 2018 [In Chinese].

10. LIANG J., WANG L.Y., CHEN Q., ZHANG W.F. Analysis and evaluation on nitrogen application status, its utilization efficiency, its influence on yield and soil fertility contribution rate to greenhouse tomato in china. China Vegetables, 10 (10), 16, 2015 [In Chinese with English abstract]. 
11. HAO T.X., ZHU Q.C., ZENG M.F., SHEN J.B., SHI X.J., LIU X.J., ZHANG F.S., DE VRIES W. Impacts of nitrogen fertilizer type and application rate on soil acidification rate under a wheat-maize double cropping system. Journal of Environmental Management, 270, 110888, 2020.

12. YANG C.Y., ZHANG Y., LI C.H., WANG C.Y. Ion composition and content changes of greenhouse soil in Ningxia. Acta Agriculturae Boreali Occidentalis Sinica, 23 (1), 201, 2014 [In Chinese with English abstract].

13. HOU G.P., ZHEN D.S., SUN N.K., JIANG Q.L., BAI C.F., LI W.H., GUO X.H. Study on soil degradation in greenhouse in Hexi corridor area. Journal of Shanxi Agricutural Unviersity (Natural science edition), 38 (1), 48, 2018 [In Chinese with English abstract].

14. LI G., ZHANG N.M., MAO K.M., SHI J., SHE L.N. Characteristics of soil salt accumulation in plastic greenhouse and its control measures. Transactions of the Chinese Society of Agricultural Engineering, 20 (3), 44, 2004 [In Chinese with English abstract].

15. GANDOIS L., PERRIN A.S., PROBST A. Impact of nitrogenous fertiliser-induced proton release on cultivated soils with contrasting carbonate contents: A column experiment. Geochimica et Cosmochimica Acta, 75 (5), 1185, 2011.

16. XU Y.Q., QIN H.L., QUAN Z., WEI W.X. Effects of long-term vegetable cultivation on the $\mathrm{NO}_{3}-\mathrm{N}$ contents in soil profile and groundwater. Research of Agricultural Modernization, 36 (6), 1080, 2015 [In Chinese with English abstract].

17. YANG Y.J., WANG J.J., KE S., SHAN Y.H., ZHANG H.P., QIAN X.Q. Effect of planting ages on soil salts content in facility cultivation watermelon soil. Chinese Agricultural Science Bulletin, 34 (35), 79, 2018 [In Chinese with English abstract].

18. SHENG H.J., DU Y., SHI K.F., SHAN Y.H., FENG K. Feasibility of mitigating the secondary salinization in greenhouse soil by carbon regulator. Journal of Plant Nutrition and Fertilizer, 22 (1), 192, 2016 [In Chinese with English abstract].

19. WU R.Y., SUN H.W., XUE J., YAN D., LIU Y., GUI D.W., WANG X.G., YANG J.Z. Acceleration of soil salinity accumulation and soil degradation due to greenhouse cultivation: a survey of farmers' practices in China. Environal Monitoring and Assessment, 192 (6), 399, 2020.

20. GU D.Y., JIAO J., GAO J.J., WANG X.F. Research progress on soil nitrate accumulation under facility condition and its effects on crops. China Vegetables, 3, 22, 2017 [In Chinese with English abstract].

21. YANG J., LU Y.F., SUN K.W., ZHEN L., QIAN X.Q., SHENG H.J. Soil nutrient in secondary salinization and soluble salt vertical distribution. Northern Horticulture, 23, 171, 2016 [In Chinese with English abstract].

22. XIANG L.L., ZHAO M.Q., WANG J., SHI Y., CHEN $X$. Effects of dicyandiamide on soil nitrate leaching and nitrate accumulation in chicory under protected cultibation. Journal of Agro-Environment Science, 28 (9), 1965, 2009 [In Chinese with English abstract].

23. LIU Q.F., LU J.L., LI S.L., SHENG H.Y., LI N., WANG Y.P., WANG J.M., ZHU C.L. The spatio-temporal variation of nitric nitrogen in protected vegetable soils in different years of cultivation. AgriculturaI Research in the Arid Areas, 29 (2), 159, 2011 [In Chinese with English abstract].

24. WEI Y.C., LI X.P., LIU G., ZHU H.J. Effect of nitric nitrogen on different greenhouse soil in Yangling area. Journal of Soil and Water Conservation, 22 (2), 174, 2008 [In Chinese with English abstract].
25. SUN Y.S., LI X.J., JIANG T., ZHENG X.M., LIANG Z.W., Electrical Conductivity Inversion Method of Saline Soil based on Sentinel-2 MSI data, 2020.

26. YUAN Q.X., ZHU D.W., ZHANG G.C. ReIationship between electrical conductivity and salt components of soil extract in plastic greenhouse. Joumal of Huazhong Agricultural University, 27 (2), 239, 2008 [In Chinese with English abstract].

27. ZHANG L.Y., ZHAO X.Q., SHEN R.F. Soil acidification and its ecological effects. Chinese Journal of Ecology, $\mathbf{3 8}$ (6), 1900, 2019 [In Chinese with English abstract].

28. LI W.H., LIU Q.Z. Changes in fungal community and diversity in strawberry rhizosphere soil after 12 years in the greenhouse. Journal of Integrative Agriculture, 18 (3), 677, 2019.

29. HAN J.P. The maechanisms for the coexistence of soil acidification and salinization under greenhouse cultivation, Doctor, Zhejiang University, 2015 [In Chinese with English abstract].

30. SONG H., ZHAO C., CAO W.C., HUANG T., WANG J.G., DONG Z.R. Changing roles of ammonia-oxidizing bacteria and archaea in a continuously acidifying soil caused by over-fertilization with nitrogen. Environmental Science and Pollution Research, 23, 11964, 2016.

31. HAN J.P., LUO Y.H., YANG L.P., LIU X.M., WU L.S., XU J.M. Acidification and salinization of soils with different initial $\mathrm{pH}$ under greenhouse vegetable cultivation. Journal of Soil \& Sediments, 14 (10), 1683, 2014.

32. WANG J.D., XU X.J., NING Y.W., ZHANG H., MA H.B., ZHANG Y.C. Progresses in agricultural driving factors on accelerated acidification of soils. Soil, 47 (4), 627, 2015 [In Chinese with English abstract].

33. DONG K.F., JI F., ZHANG B.C. Harm of soil deterioration in greenhouse and its conditioning. China Fruit Vegetable, 8 (8), 41, 2010 [In Chinese with English abstract].

34. WANG X.X., LI Q.M., CAO H., HE Y.Q., ZHANG T.L. Preliminary discussion on red soil acidification induced by plant and its mechanism. Chinese Journal of Soil Science, 35 (1), 73, 2004 [In Chinese with English abstract].

35. ZOU C.M., ZHANG D.Z., ZHANG X.H., TANG Y.L., SUN S.J., ZOU H.M. Determination and evaluation of soil acidification and salinization in Bengbu area. Anhui Agricultural Science Bulletin, 12 (9), 54, 2006 [In Chinese].

36. WANG R.X., XU Z., TANG L., ZHENG Y. Research progress on main obstacles to soil quality and rehabilitation measures in greenhouse vegetable land. Journal of Zhejiang Agricultural Science, 56 (8), 1300, 2015 [In Chinese with English abstract].

37. MA Y.C., YAO Y.X., DU Y.P., ZANG X.L., ZHAI H. Changes of soil physical and chemical propertiesi $n$ greenhouse of different grapevine planting years. Journal of Fruit Science, 32 (2), 225, 2015 [In Chinese with English abstract].

38. WANG T.H., LI P.D., ZHONG C.L. Research report on secondary salinization of vegetable soil in protected land in China. Shanxi Agricultural Economy, 6, 43, 2014 [In Chinese with English abstract].

39. CHIEN S.H., GEARHART M.M., COLLAMER D.J. The effect of different ammonical nitrogen sources on soil acidification. Soil Science, 173 (8), 544, 2008.

40. LIU T., WU X., ZHENG Z.C., LI T.X. Effects of irrigation frequency on water and salt movement in greenhouse soil. Journal of Ecology and Rural Environment, 32, 622, 2016.

41. HAN J.P., SHI J.C., ZENG L.Z., XU J.M., WU L.S. Impacts of continuous excessive fertilization on soil 
potential nitrification activity and nitrifying microbial community dynamics in greenhouse system. Journal of Soils and Sediments, 17 (2), 471, 2017.

42. ZHANG J., WANG P.C., TIAN H.M., XIAO Q.Q., JIANG H.K. Pyrosequencing-based assessment of soil microbial community structure and analysis of soil properties with vegetable planted at different years under greenhouse conditions. Soil and Tillage Research, 187, 12019.

43. SHEN W.S., NI Y.Y., GAO N., BIAN B.Y., ZHENG S.A., LIN X.G., CHU H.Y. Bacterial community composition is shaped by soil secondary salinization and acidification brought on by high nitrogen fertilization rates. Applied Soil Ecology, 108, 76, 2016.

44. XIONG W., ZHAO Q.Y., ZHAO J., XUN W.B., LI R., ZHANG R.F., WU H.S., SHEN Q.R. Different continuous cropping spans significantly affect microbial community membership and structure in a vanilla-grown soil as revealed by deep pyrosequencing. Microbial Ecology, 70 (1), 209, 2015.

45. LIU W.X., JIANG L., YANG S., WANG Z., TIAN R., PENG Z.Y., CHEN Y.L., ZHANG X.X., KUANG J.L., LING N., WANG S.P., LIU L.L. Critical transition of soil bacterial diversity and composition triggered by nitrogen enrichment. Ecology, e03053, 2020.

46. WANG X.X., CHEN Y.H., WANG J.C., ZUO Q., XIAO Q. Effects of vegetable planting ages on the physical and chemical and biologicalproperties of greenhouse soils in Beijing. Journal of Plant Nutrition and Fertilizers, 24 (6), 1619, 2018 [In Chinese with English abstract].

47. OUYANG X.J., ZHOU G.Y., HUANG Z.L., LIU J.X., ZHANG D.Q., LI J. Effect of simulated acid rain on potential carbon and nitrogen mineralization in forest soils. Pedosphere, 18 (4), 503, 2008.

48. YANG J.M., FAN P.S., WANG Y.T., GUO J.Y., LAI C.Y., SUN P., LI B.Y., WANG B.B., RUAN Y.Z., ZHAO Y. Effects of different pineapple varieties on soil properties and culturable microflora in continuous cropping banana orchard. Microbiology China, 47 (8), 2471, 2020 [In Chinese with English abstract].

49. SONG Y., XU M., LI X.N., BIAN Y.R., WANG F., YANG X.L., GU C.G., JIANG X. Long-Term Plastic Greenhouse Cultivation Changes Soil Microbial Community Structures: A Case Study. Journal of Agricultural and Food Chemistry, 66, 8941, 2018.

50. XIE Y.Q., MAO J., WANG W., ZHANG Z.D., ZHU J., GU M.Y., TANG Q.Y., SONG S.Q., HUANG W., WANG B., ZHANG L.J. Structures and biodiversity of fungal communities in rhizosphere soil of root rot diseased garlic. Chinese Agricultural Science Bulletin, 36 (13), 145, 2020 [In Chinese with English abstract].

51. WANG J.Z., YANG Y.F., HU X.Y. Developing soil remediation in vegetable fields under protected facilities to maintain sustainable production. Shanghai Agricultural Science and Technology, 4, 102, 2013 [In Chinese with English abstract].

52. GE X.Y., CHEN Q., SUN Z.G., HE C.E., LI T., ZHU O.Y. Nitrogen and straw applications increase population size of bacillus and pseudomonas spp. In greenhouse soil. Journal of Resources and Ecology, 6 (5), 293, 2015.
53. MING X. Study on potential of bacillus spp. and pseudomonas spp. pgpr in promoting plant growth and controlling disease. Oxidation Communications, 40 (2), 731, 2017.

54. RASHID A., AHMED H.U., XIAO Q., HWANG S.F., STRELKOV S.E. Effects of root exudates and $\mathrm{pH}$ on Plasmodiophora brassicae resting spore germination and infection of canola (Brassica napus L.) root hairs. Crop Protection, 48 (48), 16, 2013.

55. YIN R., ZHANG H.Y., HUANG J.F., LIN X.G., WANG J.H., CAO Z.H. Comparison of microbiological properties between soils of rice-wheat rotation and vegetable cultivation. Plant Nutrition and Fertilizer Science, 10 (1), 57, 2004 [In Chinese with English abstract].

56. YANG H.T., AN F.H., ZHAO D.D., ZHANG L., ZHU W.D., YANG F., WANG Z.C. Biological characteristics responses of alfalfa (Medicago sativa L.) to soil salinity - alkalinity. Soils and Crops, 8 (3), 242, 2019 [In Chinese with English abstract].

57. GHEHSAREH A.M. Effect of soil acidification on growth indices and microelements uptake by greenhouse cucumber. African Journal of Agricultural Research, 7 (11), 1659, 2012.

58. CHEN T.X., SUN Q., GU X., WANG R. Research progress of continuous cropping obstacles of amenities vegetable and its control measure. Northern Horticulture, 10, 193, 2016 [In Chinese with English abstract].

59. LEI F., TAN H., XIAO T.B., FU C.L., LIU G.B., ZHANG D.M., WU Y.J., ZHANG W. Amelioration of Zea mays on Secondary Salinization of Vegetable Greenhouse Soil. Chinese Journal of Tropical Crops, 41 (2), 237, 2020 [In Chinese with English abstract].

60. YAN Y.M., LI K. Effect of subsurface drainage on soiltomato system and its comprehensive benefit evaluation. Journal of Henan Agricultural Sciences, 43 (11), 49, 2014 [In Chinese with English abstract].

61. YU D.D., SHI H.B., LI Z., MIAO Q.F., DOU X., TIAN F., ZHOU L.Y. Distribution characteristics of water and salt under closed saline drainage pipe and water-saving irrigation in saline soils. Journal of Water Resources and Water Engineering, 31 (4), 252, 2020[In Chinese with English abstract].

62. LI X.J. Soil ecological problems and cleaner production measures in facility horticulture. Guangdong Science and Technology, 22 (6), 90, 2013 [In Chinese with English abstract].

63. JIANG G.J., WANG J.K., SHAO W.Q., REN Y.Q. Study on reducing soil salinity in protected areas. Water Saving Irrigation (3), 49, 2016 [In Chinese with English abstract].

64. ZHANG J.Z., WANG Z.H., HUDAN TUMAREBI Distribution characteristics of one-dimensional vertical infiltration water and salt in layered soil with subsurface straw layer. Soils, 46 (5), 954, 2014 [In Chinese with English abstract].

65. SHI W.M., JING Y., FENG Y. Vegetable cultivation under greenhouse conditions leads to rapid accumulation of nutrients, acidification and salinity of soils and groundwater contamination in South-Eastern China. Nutrient Cycling in Agroecosystems, 83, 73, 2009. 